\title{
ПРИРОAHИЧO-ГЕОГРАФ/4/HI 口OCПIOKЕHНЯ
}

УДК $551.35(262.5)$

DOI: https://doi.org/10.15407/ugz2019.01.008

Ю. Д. Шуйський, Г. В. Вихованець, Д. О. Панкратенкова

Одеський національний університет імені І. І. Мечникова

\section{ОСНОВНІ РИСИ АНТРОПОГЕННОГО ВПЛИВУ В БЕРЕГОВІЙ ЗОНІ ЧОРНОГО ТА АЗОВСЬКОГО МОРІВ У МЕЖАХ УКРАЇНИ}

\begin{abstract}
Мета публікації - виклад результатів дослідження сучасного стану берегової зони Чорного та Азовського морів у межах України в умовах неконтрольованого антропогенного впливу та отримання первинних географічних даних для подальшого забезпечення оптимального природокористування. Представлено результати досліджень упродовж 2015-2018 рр. чотирьох типових берегових областей: Дунайської, Північно-західної та Дніпровсько-Каркінітської на Чорному морі, а також Північно-Азовської на Азовському морі. Охарактеризовано вплив різних споруд (берегозахисних, рекреаційних, портових, навігаційних та інших) на берегову зону цих морів. Серед основних наслідків антропогенної діяльності в межах морського узбережжя найбільше вираженими $є$ абразійно-зсувні та абразійно-звальні процеси різних типів, зміни рельєфу акумулятивних форм, розмиви пляжів, зменшення запасів пляжеутворювальних наносів, знищення берегової флори та фауни. Визначено, що нині використання природних ресурсів у береговій зоні морів у межах України є нераціональним, тому що немає кваліфікованого природного обгрунтування, а будівництво та експлуатація споруд ведуться з порушеннями природоохоронного законодавства. Для збереження та відновлення природних ресурсів морського узбережжя необхідно проводити наукові дослідження з урахуванням фізикогеографічних умов та антропогенного впливу.
\end{abstract}

Ключові слова: берегова зона; берегозахист; наноси; абразія; поселення; антропогенний вплив; Чорне море; Азовське море.

\section{Yu. D. Shuisky, G. V. Vykhovanetz, D. O. Pankratenkova \\ Odesa I. I. Mechnikov National University \\ THE MAIN FEATURES OF ANTHROPOGENIC IMPACT IN THE COASTAL ZONE \\ OF THE BLACK AND AZOV SEAS WITHIN UKRAINE}

The purpose of the publication is to present the results of research on the present state of the coastal zone of the Black and Azov seas within Ukraine under conditions of uncontrolled anthropogenic influence and obtaining primary geographic data for the further provision of optimal nature management. The results of researches of four typical coastal areas during the period 2015-2018 are presented: Danube, Northwest and Dnipro-Karkinitskaya on the Black Sea, as well as the North Azov Sea on the Azov Sea. The influence of various structures (coastal protection, recreational, port, navigational, etc.) on the coastal zone of these seas is characterized. Among the main effects of anthropogenic activities within the seaside are the most pronounced abrasive-shear and abrasive-bridging processes of various types, changes in the relief of accumulative forms, beach erosion, reduction of reserves of beach-forming sediment, the destruction of coastal flora and fauna. It is determined that nowadays the use of natural resources in the coastal zone of the seas within the boundaries of Ukraine is irrational because there is no qualified natural justification, and the construction and operation of the facilities are being violated by environmental legislation. During 2-3 decades, continuous stealing of coastal deposit from beaches, bars, terraces, and overflows to such an extent has taken place, which has led to a sensitive increase in abrasion and erosion of accumulative forms, loss of coastal areas with all that is located on them. In the 90s of the twentieth century, a special genetic strategy for the rational usage of the coastal zone resources, including within the seas of Ukraine, was developed. But in current years, it is not used in Ukraine, because it needs some, but a little expenses. In order to preserve and restore the natural resources of the seaside, it is necessary to conduct scientific research taking into account physical and geographical conditions and anthropogenic impact.

Keywords: coastal zone; coastal protection; sediments; abrasion; settlements, anthropogenic impact; Black Sea; Sea of Azov.

() Ю. Д. Шуйський, Г. В. Вихованець, Д. О. Панкратенкова, 2019

ISSN 1561-4980. Ukr. geogr. ž, 2019, 1(105) 


\section{Актуальність теми дослідження}

Морські береги $є$ найбільш привабливими та цінними місцями на Землі, тому за останні півстоліття чисельність населення в цих приморських регіонах зросла в рази [1]. Берегова зона являє собою унікальну природну систему, де взаємодіють усі складові географічної оболонки. Проте неупорядкована урбанізація та прогресивний розвиток інфраструктури в поєднанні $з$ неузгодженими промисловими, транспортними, рекреаційними, берегозахисними, рибальськими, сільськогосподарськими та іншими видами діяльності призводять до швидкої деградації берегів [2]. Значний антропогенний тиск на навколишнє середовище в береговій зоні веде до скорочення відкритих просторів та унікальних форм рельєфу, рослинного й тваринного світу та інших природних об'єктів.

Берегова зона Чорного та Азовського морів має важливе господарське, рекреаційне, культурне та природоохоронне значення, що зумовлює необхідність дослідження іiі сучасного стану для збереження природних ресурсів [3, 4]. Упродовж останніх десятиріч морське узбережжя у межах України зазнало значних змін, що потребують докладного аналізу. Для подальшого раціонального природокористування, збереження природи та, зокрема, бальнеологічних ресурсів, потрібно враховувати різні зміни, кожна $з$ яких має бути досліджена та предметно оцінена. Відповідно, матеріали досліджень можуть бути покладені в основу обгрунтування подальшого раціонального природокористування, планування організації території, стратегії забудови, боротьби з негативними явищами тощо.

Все це зумовлює актуальність виконаного дослідження. Упродовж минулих років така робота не виконувалася в належному обсязі, тому що відповідні центральні та місцеві установи практично не фінансували спеціальні прибережно-морські дослідження. Такий стан не забезпечував можливість отримувати відповідну інформацію на підставі теорії берегознавства, при цьому нагальність таких робіт є очевидною.

\section{Аналіз останніх досліджень і публікацій}

Серед нещодавних праць, що стосуються теми дослідження, можна виділити наукові статті Ю. Д. Шуйського, Г.В. Вихованець, Л. В. Орган та Д.О. Панкратенкової про розвиток морської окрайки дельти Дунаю [5], динаміку прибережно-морських акумулятивних форм рельєфу [6,
7], деградацію акумулятивних форм Чорноморського узбережжя та причини цих явищ [8]. Нову інформацію отримано шляхом польових досліджень О. Б. Муркалова та його співавторів [9] про зміни якості води, рельєфу в акваторіях Сухого та Великого Аджалицького лиманів у зв'язку з їх поглибленням та необхідністю побудови нового мосту. За власні кошти місцевих жителів продовжуються малоефективні роботи в різних приморських лиманах Чорноморського узбережжя [10]. Берегова зона зазнала суттєвих змін, на жаль, переважно негативних. Останніми роками з'являються результати нових досліджень Азовського моря, які «...спрямовані на удосконалення природокористування та на безпосереднє забезпечення діяльності морських портів, судноплавних каналів, підводних кар'єрів тощо» [11]. За відсутності натурних експериментальних досліджень впродовж останніх двох-трьох десятиріч, багато уваги було присвячено загальнотеоретичним, науково-методологічним дослідженням [12]. Серед картографічних праць можна назвати Океанографічний атлас Чорного та Азовського морів: Розділ 2. Берегова зона Чорного моря [13].

При цьому слід зазначити, що сучасний загальний стан берегів України так і залишається неналежно дослідженим, якщо враховувати антропогенні впливи та виклики останніх років, а відтак суттєво загальмовується раціональне використання природних ресурсів та збереження берегової зони Чорного та Азовського морів.

М е т ю ю цієї роботи є виклад результатів дослідження сучасного стану берегової зони Чорного та Азовського морів у межах України в умовах неконтрольованого антропогенного впливу та отримання первинних географічних даних для подальшого забезпечення оптимального природокористування. Упродовж 2015-2018 рр. нами було проведено фізико-географічні дослідження, де в загальному вигляді обстежено чотири типові берегові області: Дунайська, Північно-західна та Дніпровсько-Каркінітська на Чорному морі та Північно-Азовська на Азовському морі (puc. 1). Були застосовані головним чином методи маршрутно-експедиційний, картографічний, фотографічний, дистанційний, порівняльно-географічний, аналітичний, графічний.

\section{Виклад основного матеріалу}

Останніми роками в названих берегових областях Чорного та Азовського морів відзначається суттєвий антропогенний вплив. Це стосується 


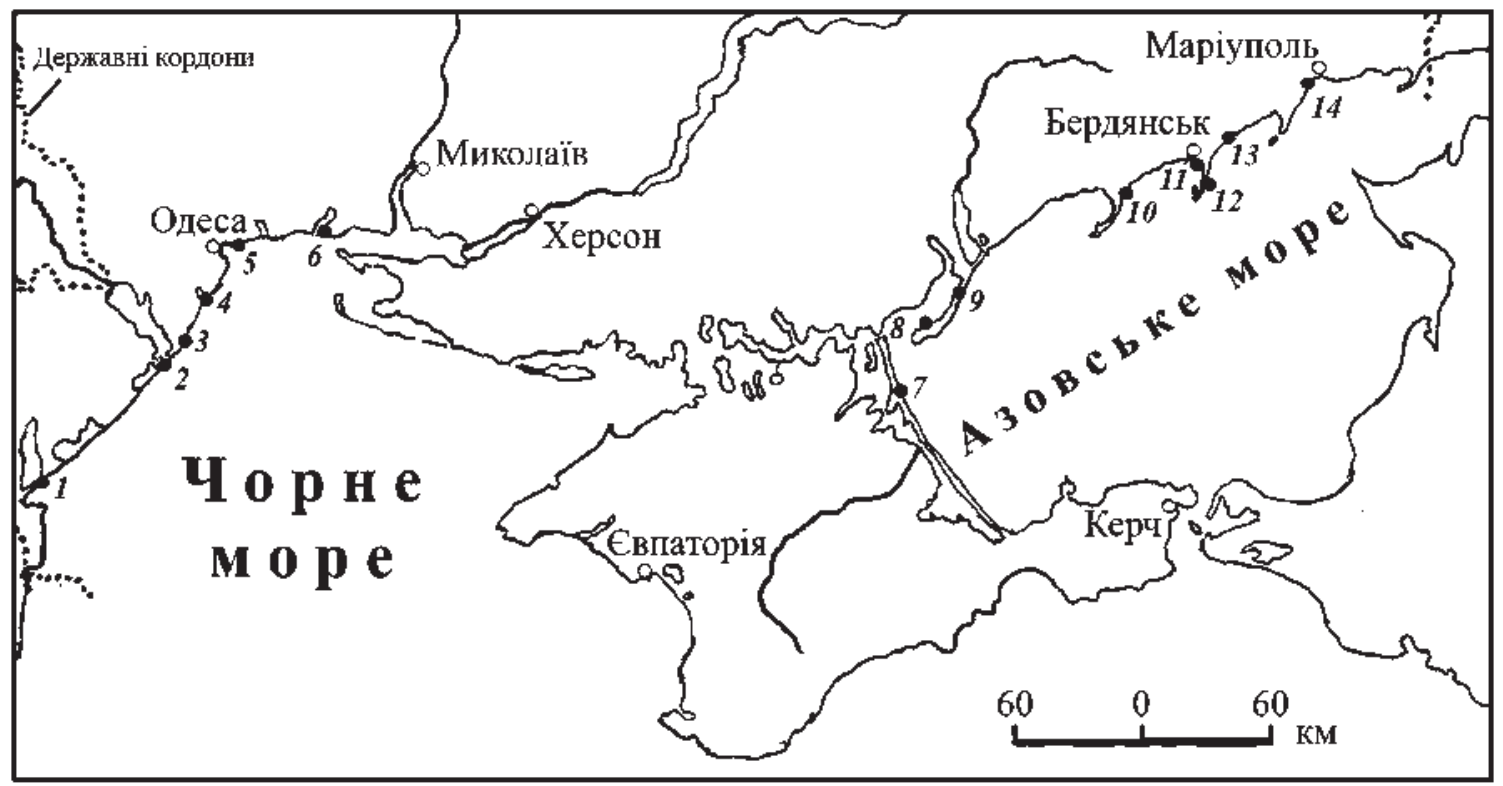

Puc. 1. Карта Чорного та Азовського морів.

Умовні позначення: Чорні круги -місцезнаходження антропогенно перетворених берегових ділянок: 1 - пересип лиману Сасик; 2 - частина пересипу Дністровського та Будаџького лиманів; 3 - Тернівська тераса; 4 - порт Іллічівськ; 5 - селище Фонтанка; 6-порт Южний; 7 -коса Арабатська Стрілка; 8-коса Бирючий Острів; 9 - Федотова коса; 10 - Обитічна коса; 11 - порт Бердянськ; 12 - Бердянська коса; 13 - гирло р. Берда; 14 - порт Маріуполь

рельєфу, балансу наносів, якості води, стану рослин і тварин тощо. Найбільші зміні відбулися щодо форм рельєфу та динамічних показників прибережно-морських контактних систем, тобто акваландшафтів [12]. Основні види антропогенного впливу розподілені нерівномірно, як прямі, так і непрямі, як показано на рис. 1. Найбільший антропогенний тиск притаманний ділянці від Одеської затоки на південний захід до південної частини Будацького лиману і на схід до Очакова, а також між Маріуполем та Бердянськом у межах Азовського моря.

Серед основних видів антропогенного втручання в природу берегової зони морів слід виділити прямі вилучення наносів 3 пляжів, барів, пересипів, з підводного схилу [6]. Справа в тому, що приморська частина Причорноморської низовини складена глинистими та слабкими скельними карбонатними породами неоген-антропогену. По-перше, їх шаруватість спричинює розвиток зсувів. По-друге, внаслідок абразії цих порід у кліфах утворюється незначна кількість наносів хвильового поля - пересічно 1,0-2,5 м $3 /$ м.рік на Чорному морі та 2-3 м³/м'рік на Азовському морі протягом останніх десятиріч. Такі скиди осадового матеріалу відбуваються в умовах сильного хвильового впливу (зусилля однієї хвилі дорів- нюють до 9-10 т/м²) і під впливом високих швидкостей абразії (пересічно 1,5-3,0 м/рік [6, 14]). Це трохи більше, ніж на досліджених берегах Чорного моря. По-третє, наноси з берегової зони дуже добре відсортовані, непилуваті, найдешевші для будівництва. Тому часто з поверхні притулених односхилових пляжів наноси вивозять тракторами або вантажівками для будівництва фактично в кожному береговому населеному пункті для житлових будинків, дач, баз відпочинку, шляхів тощо. Особливо багато наносів (пісків, гравію, гальки) вилучається з акумулятивних форм рельєфу (пересипів, барів, терас тощо). Разом з верхнім шаром піску, що вивозиться, фізично невідновно масово гинуть рослини, тварини, поживні розчини, зникає природна структура пляжевого шару.

Наноси вилучають також і з підводного схилу - з реліктів банок, давніх піщаних форм, великих покривних плям. Найсильніше потерпають унікальні фізико-географічні системи, які трапляються тільки на піщаних акумулятивних формах берегової зони, 3 незвичною сумою елементів та компонентів, $з$ індивідуальними шляхами розвитку, з дуже напруженою взаємодією структурних складових будови $[7,8]$.

Упродовж останніх 20 років тільки з досліджених нами пляжів Чорного моря було вивезено понад 7 млн т піщаних наносів між мисом Великий 
Фонтан та Жебріянською бухтою. Така кількість надходила до берегової зони у природному стані кожного року. Цих надходжень вистачало тільки для підтримки динамічної рівноваги та результативного слабкого розмиву акумулятивних форм рельєфу і дефіциту наносів, який безперервно підтримує загальну деструкцію (в т. ч. абразію) у береговій зоні. Пересічно це становить трохи більше 350 тис. т/рік, або стільки ж, скільки в природних умовах скидалося із річок, еолових полів, кліфів та бенчів у межах берегової зони між Одеською затокою та Жебріянською бухтою [12].

Яскравим прикладом шкідливого впливу діяльності людини $€$ пересип Дністровського лиману, де розташоване смт Затока. Всю забудову цього селища та північної половини Будацького пересипу виконано 3 використанням місцевого піску, його природного накопичення. За останні 25 років було вилучено шар близько 4 м товщиною, що дорівнює пересічному використанню 16 см/рік піску. I це з урахуванням майже 35\% природної компенсації. Таке зниження природної висоти Дністровського пересипу властиве насамперед для сучасних еолових кучугур, пляжів та берегових валів $[4,8]$. Отже, загальна висота пересипу настільки знизилася, що це призвело до зникнення післяштормових компенсацій наносів та до появи штормових затоплень поверхні пересипу.

До сьогодні існує низка підводних кар'єрів: Одеська Банка, Тендрівська Банка, Тернівський кар'єр, Піщаний кар'єр та інші. Видобувають пісок також на Бірючому Острові, на Федотовій та Бердянській косах, подекуди - на півночі Арабатської Стрілки, на численних пляжах тощо. Зокрема пересічно 300 тис. т/рік піщано-черепашкової суміші упродовж останніх 25 років видобувалося між Кривою косою та Арабатською Стрілкою. Їх було використано для зведення багатьох сотень різних будівель, бетонних блоків, фундаментів, кілометрів шляхів тощо.

Є підстави стверджувати, що обсяги штучного вилучення прибережно-морських наносів більші від природного на порядок величини [7,8]. Не меншими $€$ штучні втрати берегових наносів на північній половині Будацького пересипу та на піщаній терасі Вовчок на березі поблизу селища Жебріяни (Приморське).

Зовнішні гідротехнічні споруди (підхідні канали, навігаційні виїмки, захисні моли, буни тощо) навколо морських портів затримують до 30-50\% наносів від обсягу вздовжберегових потоків наносів, наприклад, порти Іллічівськ та Южний на узбережжі Чорного моря, Маріуполь та Бердянськ на узбережжі Азовського моря. Зокрема, споруди порту Южний перехоплюють до $40 \%$ Аджияського потоку наносів. I це ще сильніше загострює дефіцит наносів та перетворює осередок акумуляції в Одеській затоці на ділянку динамічної рівноваги, а на абразійних ділянках в 2-3 рази знижуються розміри захисних пляжів, що підсилює повторюваність й активізацію зсувів $[6,12]$. Після будівництва гавані для малих суден біля мису Північного Одеського лузанівські пляжі в Одеській затоці зазнали відчутного розмиву $[7,8]$. Всі названі штучні вилучення наносів призвели до зменшення розмірів односхилових пляжів та надводної частини барів і пересипів.

Майже всі дослідники-берегознавці стверджують, що високі швидкості абразії кліфів спричинюють інтенсивну абразію підводного схилу, а разом вони поглинають великі площі берегової території, в сумі - десятки гектарів на рік у межах країни. Оскільки нині на морських берегах України майже не проводяться роботи 3 кваліфікованого інженерного захисту берегів, запобігання втрат берегової території, то місцеві мешканці та органи самоврядування, користувачі морських ресурсів самотужки на свій розсуд виконують примітивний берегозахист. Та увесь цей процес і його наслідки, що позбавлені географічного берегового обгрунтування, призводять до ще більшого зростання шкідливих процесів $[6,12]$. Так, в районі Бердянська на узбережжі Азовського моря бетонними та залізобетонними спорудами блоковано суглинистий абразійний берег, що був джерелом наносів для зворотного потоку наносів уздовж західного берега Бердянської коси.

Тому цей берег, зазнаючи підвищеного дефіциту наносів, почав сильно руйнуватися (puc. 2), причому разом з усіма зведеними тут будівлями. Їх частина ще збереглася ( $\approx 30 \%$ від первинної), а велику кількість змило море.

Бажання зупинити відступ берегів (швидкість абразії 1,5 м/рік) та їх руйнацію на південь від мису Великий Фонтан (Чорне море) спонука-ло місцевих жителів виставити бетонну захис-ну стіну та широкі берми, із кам'яними накидами включно (puc. 3). 3 такими спорудами море справляється без перешкод, тільки ось пляжі зникли повністю. Біля мису Північного Одеського, де в XX ст. природна швидкість абразії зсувного 


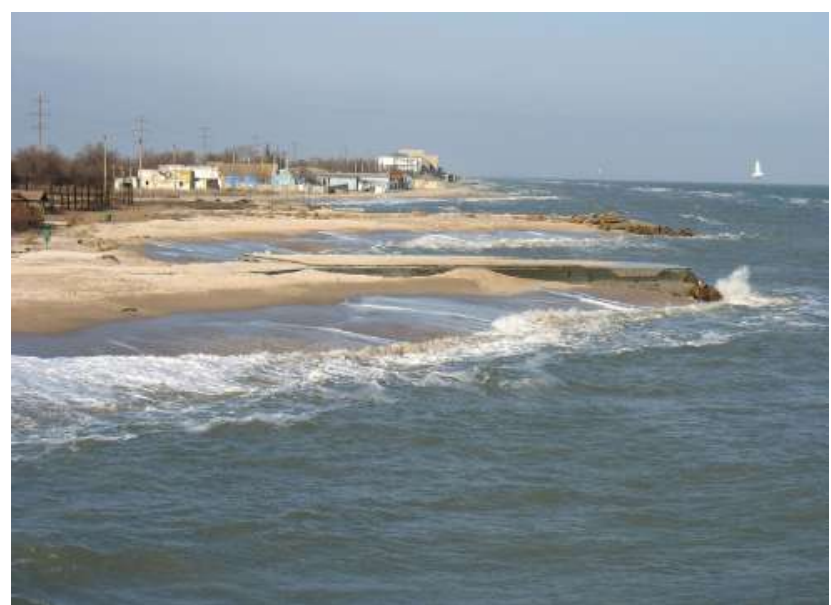

Puc.2

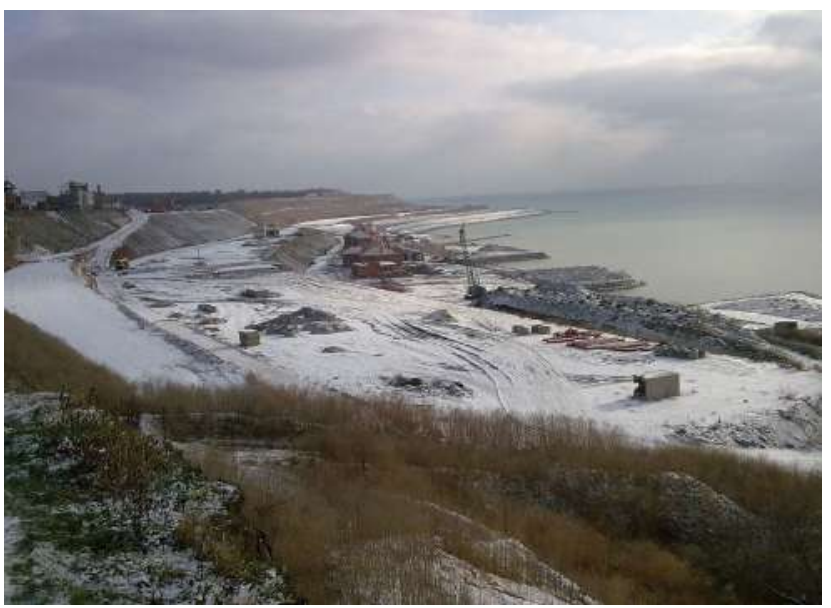

Puc. 4

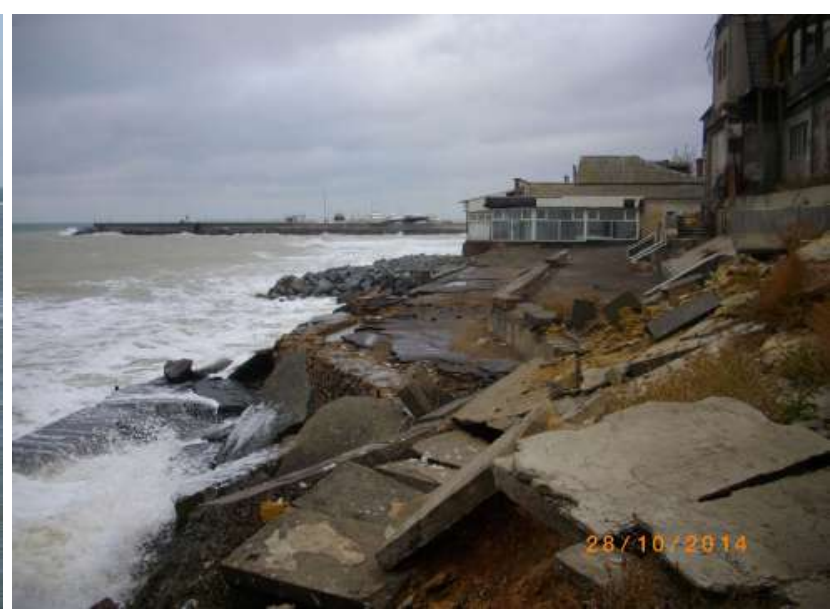

Puc. 3

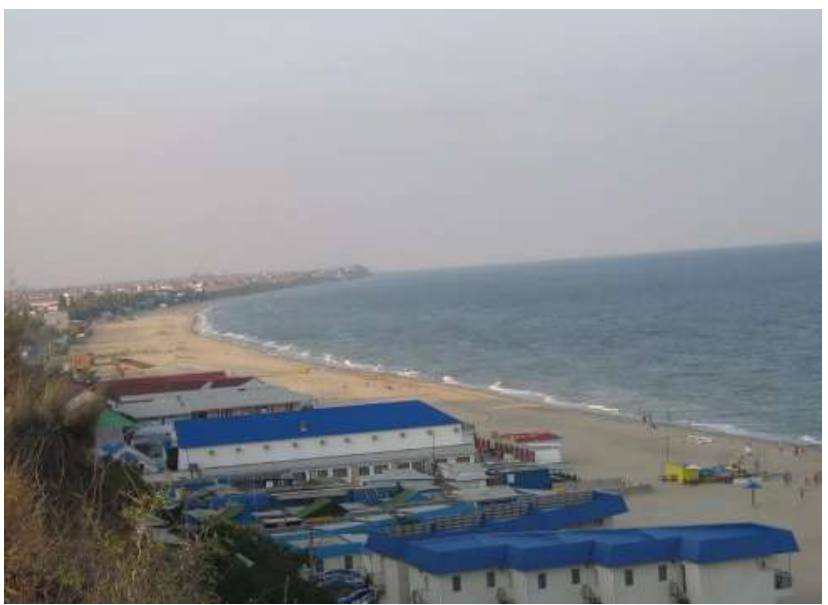

Puc. 5

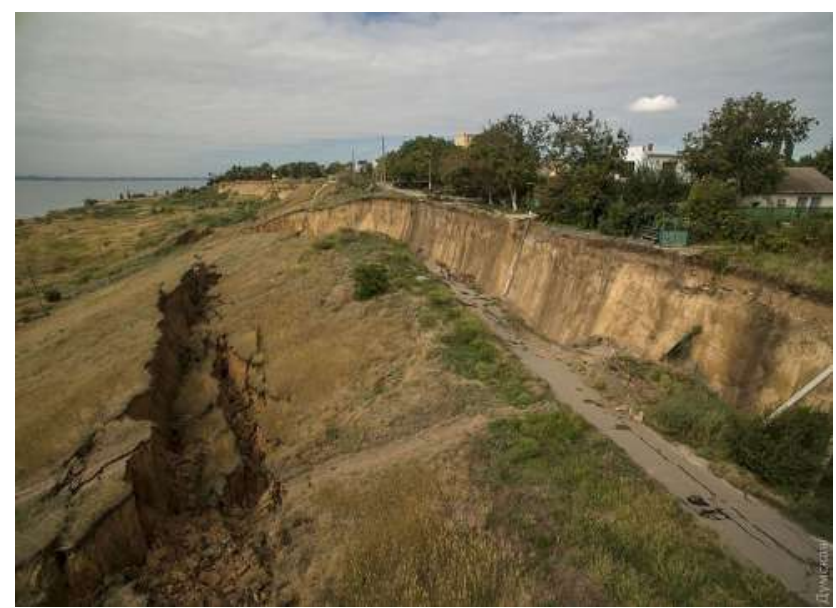

Puc. 7

Puc. 2. Ознаки розмиву західного берега Бердянської коси (Азовське море) восени 2017 р. При будівництві бунів не було враховано баланс наносів та їх конструкцію

Puc. 3. Залишки непрофесійно побудованого берегозахисту у вигляді бетонної берми та кам'яних накидів на березі селища Люстдорф (Одеса)

Puc. 4. Широка штучна тераса ускладнила можливість надходження наносів з кліфів на пляжі Одеської затоки, що сприяло розвитку режиму розмиву пляжів

Puc. 5. Штучно перероблена піщана Тернівська тераса, на якій знищені унікальні берегові комплекси. У зв'язку з тим, що тераса підвищена на +0,2-0,5 м над ординаром, вона 3-5 разів на рік затоплюється морською водою

Puc. 6. Високий забудований береговий схил на південь від мису Ланжерон до мису Великий Фонтан (на задньому плані) на березі Чорного моря в межах Одеси

Puc. 7. Глибокий береговий терасований зсув завдовжки 2,5 км (висота кліфу 52 м) на ділянці між портом Южний та Одеською затокою Чорного моря 
кліфу дорівнювала близько 3 м/рік, була побудована велика конструкція, - штучна тераса, берма (puc. 4). Вона також закрила абразійно-зсувний кліф від хвильового впливу. Його абразія і скиди наносів у берегову зону припинилися, а пляжі були позбавлені живлення та зникли.

На південь від гирла р. Барабой на піщаній Тернівській терасі були знищені всі природні пляжі та берегові еолові форми (рuc. 5), які регулярно компенсували штормові розмиви суміжних берегових акумулятивних форм рельєфу, зокрема - на пересипі Дністровського та Будацького лиманів. Великі берегові дюни були своєрідним резервом-компенсатором розмиву піщаних форм «нижче» вздовжберегового потоку наносів.

До того ж, піщані природні системи 3 еоловим рельєфом $є$ унікальними природними комплексами, які трапляються тільки на морських берегах $[6,12]$, а в усьому світі вони є об'єктами найсуворішої охорони, входять до заповідників та національних парків. За оригінальністю та екологічним різноманіттям вони не мають аналогів у світі, але на берегах України фізично знищуються як на Чорному, так і на Азовському морях. Зокрема, десять років тому в північній частині Дністровського пересипу був знищений гай дикої маслини (лох гостролистий), що мав довжину до 3 км, а ширину щонайменше 400-450 м. Такий квітучий великий гай здорових дерев, та ще в умовах періодичного впливу морських хвиль, був єдиним на території України і міг би претендувати на національну пам'ятку природи.

Слід зазначити, що новий Генеральний план забудови смт Затока також не передбачає заходів проти руйнації природи на пересипу Дністровського лиману.

Загалом порушення екологічного законодавства, неконтрольована господарська діяльність, що відбувається в межах району дослідження, активна і хаотична забудова, яка часто має місце на схилах абразійних берегів (рис. 6) спостерігається майже на всьому Азово-Чорноморському узбережжі: на пересипах, косах, терасах, барах поблизу берегової лінії, незважаючи на гостру небезпеку зсувів $[6,12,14,15]$. На таке порушення природного балансу досить швидко реагують абразійно-зсувні процеси, як приклад - катастрофічні зсуви поблизу м. Бугове, селища Фонтанка, міста Южний на Чорному морі (puc. 7). Разом із цими процесами припиняється надходження 3 абразійних джерел осадового матеріалу для по- повнення наносів на пляжах і більших акумулятивних формах рельєфу.

\section{Висновки}

На підставі детального аналізу сучасного стану берегової зони Чорного та Азовського морів у межах України можна зробити такі висновки.

1. Смуга берегової зони Чорного та Азовського морів у межах України відносно щільно забудована портовими, навігаційними, берегозахисними, рекреаційними, сельбищними та іншими спорудами. Упродовж останніх десятиріч використання природних ресурсів берегової зони морів у межах України є нераціональним, без кваліфікованого обгрунтування, а будівництво та експлуатація споруд ведуться з порушеннями природозахисного законодавства, що призвело до швидкого процесу виснаження берегів, деградації та погіршення стану навколишнього середовища.

2. Впродовж останніх 2-3 десятиріч відбувається незаконне використання берегових наносів із поверхні пляжів, барів, терас, пересипів тощо для різних видів будівництва. Зменшення кількості наносів призвело до посилення абразії та розмиву акумулятивних форм рельєфу, втрат берегових територій $з$ усіма розташованими на них обєктами. Зменшуються обсяги пляжеутворювальних наносів на захисних пляжах та кучугурах, що посилює вплив хвиль різних типів на абразійні форми берегового рельєфу.

3. Насиченість берегової зони штучними формами-спорудами (наприклад, довгими бунами, судноплавними каналами, портовими молами, підводними карєрами тощо) зазвичай веде до концентрації маси наносів на кожній споруді, на невеликій ділянці за рахунок зменшення розмірів навколишніх захисних пляжів, барів, пересипів на решті довжини цієї смуги. Розподіл наносів стає нерівномірним, розбалансованим, що посилює розмив хвилями та хвильовими течіями осередків накопичення, активізуються загальні втрати захисних наносів по всій довжині берегової зони.

4. В 90-х роках XX ст. було розроблено спеціальну стратегію раціонального використання ресурсів берегової зони морів, у тому числі й морів у межах України, але останніми роками на території нашої держави вона не діє, зокрема у зв'язку з тим, що потребує певних витрат, а більшість природокористувачів уникають витрат для збереження природи берегової зони морів.

5. Для збереження природних ресурсів берегової зони Чорного та Азовського морів у межах 
України необхідно удосконалити діючу природоохоронну законодавчу базу. Для обгрунтування подальшого використання берегової екосистеми слід проводити відповідні дослідження, зокрема спеціалістами-географами, 3 комплексним підходом до розуміння прибережно-морських процесів.

\section{References [Лimepamypa]}

1. Schwartz M. L. (1982). Encyclopedia of Beaches and Coastal Environments. Vol. XV of Encycl. Earth Sci. Series. Stroudsburg, $940 \mathrm{p}$.

2. Shepard F. P., Wanless I. F. (1971). Our Changing Coastline. New-York: McGrow-Hill Book Co, 579 p.

3. Shuisky Y. D. (1999). Relative changes of the Black Sea level and impact of abrasive shores processes. Geografia Fisica e Dinamica Quaternaria, Vol. 22, 2, 87-97.

4. Yanko-Hombach V. B., Gilbert A. S., Panin N. S. \& Dolukhanov P. M. (2005). Climate dynamics, Sea-level change, and shoreline migration in the Ukrainian sector of the Circum-Pontic Region. The Black Sea Flood Question: Changes in Coastline, Climate, and Human Settlement, 251-277.

5. Shuisky Yu. D., Organ L. V. (2017). Pioneer landforms on the sea edge of the Kiliya delta of the Danube River. Scientific Notes of the Vinnitsa State University. Series Geography. Iss. 29, 3-4, 15-25. [In Russian].

[Шуйский Ю. Д., Орган Л. В. Пионерные формы рельефа на морском крае Килийской дельты реки Дунай // Наукові записки Вінницького держ. ун-ту. Серія: Географія. 2017. Вип. 29. № 3-4. С. 15-25.]

6. Shuisky Yu. D., Vikhovanets G. V. (2011). Nature of the Black Sea estuaries. Odessa, 276 p. [In Russian]. [Шуйский Ю. Д., Выхованец Г. В. Природа Причерноморских лиманов. Одесса, 2011. 276 с.]

7. Shuisky Yu. D., Vikhovanets G. V. (2017). Modern dynamics of sandy accumulative forms of relief in the coastal zone of the Black Sea. Slovak Intern. Scientific Journal (Bratislava). Iss. 1, 11, 22-32. [In Russian].

[Шуйский Ю. Д., Выхованец Г. В. Современная динамика песчаных аккумулятивных форм рельефа в береговой зоне Черного моря // Slovak Intern. Scientific Journal (Bratislava). 2017. Вып. 1. № 11. С. 22-32.]

8. Vykhovanets G. V., Pankratenkova D. O. (2018). Influence of the anthropogenic factor on the current state of the accumulative relief forms of the northwestern part of the Black Sea. Bulletin of the Odessa National University. Vol. 23. Iss.1 (32), 11- 32. [In Russian].

[Выхованец Г.В., Панкратенкова Д.О. Влияние антропогенного фактора на современное состояние аккумулятивных форм рельефа северо-западной части Черного моря // Вісник Одеського нац. ун-ту. Географічні та геологічні науки. 2018. Том 23. Вип. 1 (32). С. 11-32.]

9. Murkalov A.B., Stoyan A.A., Skalenchuk E.V. (2018). Spatial distribution of hydrological elements in the middle part of the dry estuary during the summer period. Bulletin of the Odessa National University. Vol. 23. Iss. 1 (32), 33-42. [In Russian].

[Муркалов А. Б., Стоян А. А., Скаленчук Е. В. Пространственное распределение гидрологических элементов в средней части Сухого лимана в летний период // Вісник Одеського нац. ун-ту. Географічні та геологічні науки. 2018. Том 23. Вип. 1 (32). С. 33-42.]

10. Shuisky Yu. D., Sinyuk A. N. (2015). Salinity in the Tiligul estuary in the fall of 2015 (Black Sea coast). Bulletin of the Odessa National University. Geographical and geological sciences .Vol. 20. Iss. 4 (27), 89-98. [In Russian].

[Шуйский Ю. Д., Синюк А. Н. Соленость воды в Тилигульском лимане осенью 2015 года (побережье Черного моря) // Вісник Одеського нац. ун-ту ім. І. І. Мечникова. Географічні та геологічні науки. 2015. Том 20. Вип. 4 (27). C. 89-98.]

11. Vorovka V. P. (2018). Azov Paradigm Landscape System. Manuscript. Thesis for a degree of doctor of geographical sciences in specialty 11.00.11. Kyiv. 41 p. [In Ukrainian].

[Воровка В. П. Приазовська парадинамічна ландшафтна система: автореф дис. ... докт. геогр. наук: 11.00.11. Київ, 2018. 41 c.]

12. Shuisky Yu. D. (2018). History of development and methodology of coastal management. Monograph. Odessa, 456 p. [In Russian].

[Шуйский Ю. Д. История развития и методология береговедения: Монография. Одесса, 2018. 456 с.]

13. Oceanographic Atlas of the Black and Azov Seas. Section 2. Black Sea Coastal Zone [Maps]. (2009). Kyiv. 356 p. [In Ukrainian].

[Океанографічний Атлас Чорного та Азовського морів: Розділ 2. Берегова зона Чорного моря [Карти]. Київ: ДУ «Держгідрографія», 2009. 356 с. ]

14. Artyukhin Yu. V. (1982). Wave destruction of landslide shores of the Azov Sea. Geomorphology, 4, 51-58. [In Russian]. [Артюхин Ю. В. Волновое разрушение обвальных берегов Азовского моря // Геоморфология. 1982. № 4. С. 51-58.]

15. Shuisky Yu. D., Stoyan A. A. (2007). Assessment of the knowledge of abrasion processes on the Ukrainian shores of the Black and Azov Seas. Fals 'kyan Readings: Coll. sciences works. 375-384. [In Russian].

[Шуйский Ю. Д., Стоян А. А. Оценка изученности абразионных процессов на украинских берегах Черного и Азовского морей // Фальцфейнівські читання: Зб. наук. праць. Херсон, 2007. С. 375-384.] 